\title{
DEPOIMENTO: ARQUITETO LUCIANO FIASCHI
}

Entrevistadores:

Prof. Dr. Silvio Soares Macedo

Arquiteta Fany Galender

Transcrição:

Demétrius Borges dos S. G. de Araujo

Edição do depoimento:

Arquiteta Fany Galender

Arquiteta Ms. Solange Moura Lima Aragão

Demétrius Borges dos S. G. de Araujo

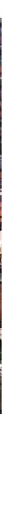




\section{RESUMO}

Iniciando a série "Ciclo de Depoimentos", organizado pelo projeto de pesquisa - Projeto Quapá - do Laboratório da Paisagem da Faculdade de Arquitetura e Urbanismo da Universidade de São Paulo, que visa ao registro da produção paisagística brasileira, foi realizada a entrevista com o arquiteto Luciano Fiaschi, formado pela FAUUSP em 1968, o qual desenvolve projetos paisagísticos em escritório próprio desde 1973, em São Paulo.

Ocupou a presidência da Associação Brasileira de Arquitetos Paisagistas (ABAP) entre 1985 e 1986.

Dedica-se à prática profissional tanto na esfera pública quanto privada, o que the garante um lugar de destaque no quadro da arquitetura paisagística nacional.

O texto que se segue é resultado da edição do material de gravação realizado no auditório da Faculdade de Arquitetura e Urbanismo da Universidade de São Paulo (FAUUSP), no dia 26 de novembro de 2003.

\section{ABSTRACT}

This is the first interview of a serie with the mais contemporary landscape architets from Brazil developed by Quapá, a research group that studies about Brazilian Contemporary Landscape Architecture.

The first interview focuses the work of Luciano Fiaschi, who did his studies in Faculdade de Arquitetura e Urbanismo da Universidade de São Paulo (FAUUSP) - 1968. He has his own office in São Paulo since 1973, where develops works to private companies government, like parks, gardens and public squares.

The interview took place in the auditorium of FAUUSP, Cidade Universitária, november $26^{\text {th }}, 2003$. 


\section{DEPOIMENTO: ARQUITETO LUCIANO FIASCHI}

Eu queria agradecer a oportunidade de inaugurar este ciclo de debates do Projeto Quapá e dar os parabéns ao projeto. Acho preciosa essa contribuição que o Projeto Quapá está fazendo na área paisagística do Brasil - desde o levantamento dos projetos, o acervo de fotos e a documentação relativa ao paisagismo - sinto-me muito orgulhoso de inaugurar essa série de depoimentos gravados.

Vou falar um pouco sobre meu percurso profissional. Na realidade, durante o período em que fui aluno na Faculdade de Arquitetura e Urbanismo não sabia exatamente o que queria fazer. A FAU atualmente chegou a um ponto em que está um pouco acima da arquitetura, e os alunos se sentem um pouco desprestigiados em ter de fazer projetos de arquitetura. Vejo pelo pessoal que estagia no escritório. Como é difícil colocar o pé desse pessoal no chão e dizer "não", que projeto é "isso" e arquiteto faz projeto.

Sentia-me bastante perdido e iniciei minha carreira profissional mais como arquiteto de edificação do que arquiteto paisagista. Eu tinha sido aluno do Roberto Coelho Cardozo, gostava bastante dos exercícios práticos dele, mas talvez não entendesse muito bem o que ele queria transmitir com aqueles exercícios, com as aulas e as palestras que fazia. Mas acho que isso era muito mais pelo fato de não estar preparado para fazer perguntas. Acho que a gente tem de estar preparado para aprender; e só comecei a entender as aulas do Cardozo e a ver como elas eram boas depois que comecei a minha prática profissional. Demorou bastante para "cair a ficha". E isso não só na área de arquitetura paisagística, mas em todas as áreas.

Lembro-me também dos trabalhos que fazíamos com Renina Katz e com Flávio Império. A gente colava quadradinhos pretos, brancos e cinzas sobre o fundo, sem saber muito bem para quê estávamos fazendo aquilo. Podíamos até ser eficientes, fazer umas coisas agradáveis, bonitas e simpáticas, mas não sabíamos de que forma aquilo estaria contribuindo para nossa formação profissional. Eu não sei se isso é uma coisa minha, ou se é uma coisa geral, que acontece com todos.

Por volta do segundo ano da FAU, comecei a fazer estágios em escritórios de arquitetura. Trabalhei, inicialmente, no escritório do arquiteto Wilson Gottardi e, depois, passei para o escritório do arquiteto Gregório Zolko, fazendo estágio na hora do almoço e de noite. Naquela ocasião, raramente os estagiários eram remunerados. Eu fazia estágio não-remunerado. 


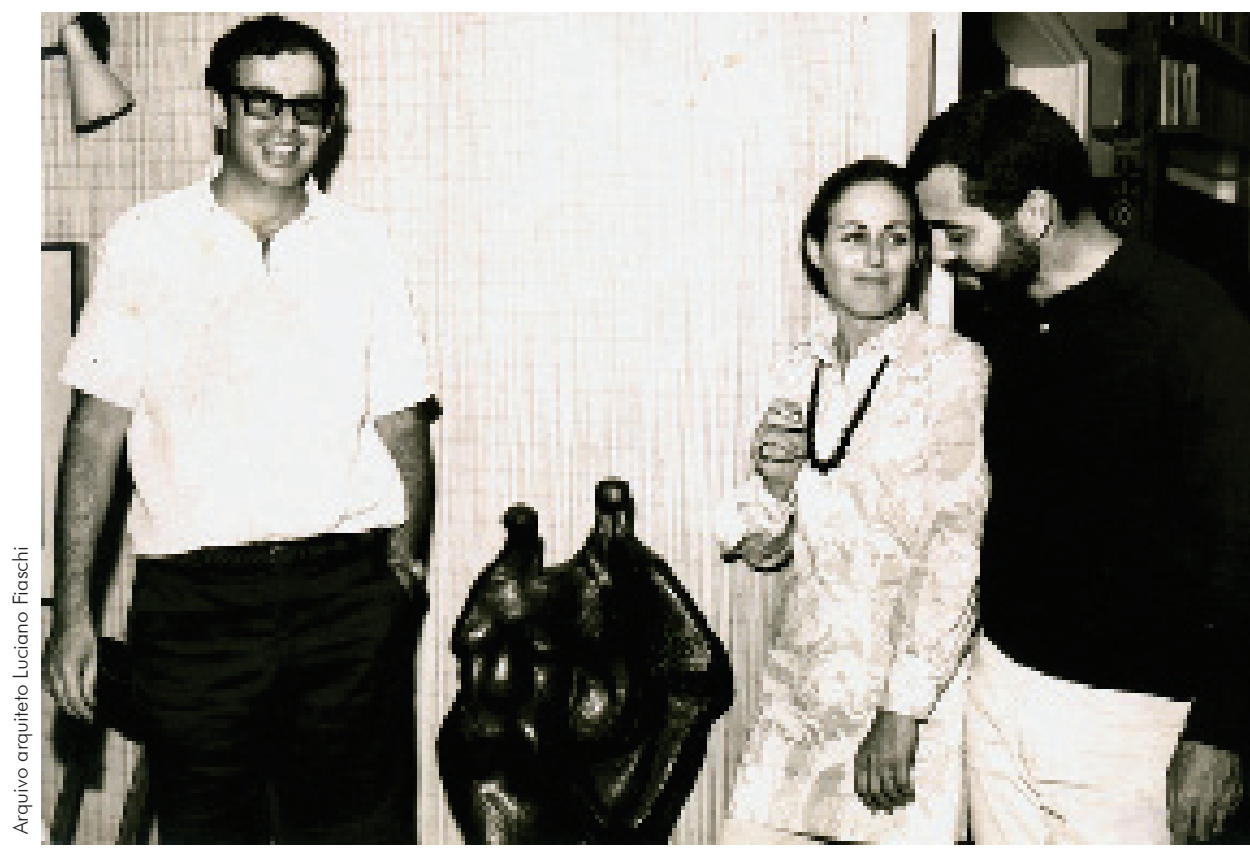

Foto 1: Cardozo (à direita) em companhia do casal Mônica e

Gregório Zolko - 1974

No escritório do Zolko, comecei a aprender a desenhar. Eu tinha como colega, também estagiário, o arquiteto Marcos de Souza Dias, que havia trabalhado com o arquiteto Zoltan Dudus, que, por sua vez, havia trabaIhado com o Oswaldo Bratke. Ele trazia toda aquela tradição do desenho a lápis, um desenho muito bacana, um desenho técnico muito eficiente. Quem conhece os desenhos do Oswaldo Bratke sabe que ele é um ótimo desenhista e, na parte do desenho técnico, também. O Dudus também era um desenhista incrível.

Comecei a aprender a desenhar com o Marcos de Souza Dias. Posteriormente, levado pelo próprio, fui trabalhar no escritório do Roberto Coelho Cardozo. Na ocasião, o escritório era composto por dois arquitetos: o Antônio Augusto Antunes Neto, que também era professor aqui da FAU, e o Marcos de Souza Dias, recém-formado - além do Cardozo, que era uma pessoa de arquitetura paisagística e vinha de uma formação junto ao escritório do (Garrett) Eckbo, nos Estados Unidos.

Fazendo um parêntese para explicar a trajetória do Cardozo, ele veio para o Brasil, não sei exatamente quando, com sua esposa. Ele era norte-americano, de origem portuguesa, e sua esposa, Susan Osborn, também trabalhava com arquitetura paisagística. A Suzan pertencia a uma família americana tradicional da Califórnia. Ambos trabalharam com o Garrett Eckbo nos Estados Unidos e vieram para o Brasil com uma carta de recomendação dirigida a (Roberto) Burle Marx, e instalaram-se no escritório dele, no qual começaram suas carreiras profissionais aqui no Brasil. Ficaram pouco tempo lá. Depois, mudaram-se para São Paulo, também com uma carta de apresentação do Eckbo dirigida ao professor (João Batista Vilanova) Artigas. O Cardozo veio 
para a FAU; a Susan teve uma atuação bastante boa junto a revistas do tipo Arquitetura e Construção. Na época, acho que só existia a revista Cláudia fazendo artigos e reportagens sobre projetos de arquitetura paisagística. Ela teve uma atuação menor do que ele na área de projeto, mas fez coisas muito interessantes.

Cheguei no escritório do Cardozo em 1967/68, ainda como estudante de arquitetura, mais para trabalhar com os arquitetos do escritório. Na realidade, tive pouco trabalho direto com o Cardozo. Ele não tinha uma equipe; trabalhava praticamente sozinho. Projetava e desenhava seus projetos com uma qualidade de desenho muito boa. Eram desenhos que não passavam por uma etapa de croquis ou rabisco; saíam direto já como projetos executivos. Era uma coisa impressionante. Realmente fiquei muito impressionado e transformei-me em um desenhista muito bom, muito eficiente. Na época, o escritório estava projetando a Praça Roosevelt. Desenhei aquelas "duzentas" pranchas duas vezes, porque no meio do projeto - os originais ficavam no escritório do Figueiredo Ferraz - o escritório pegou fogo e queimou tudo. Desenhei tudo de novo e tornei-me ótimo desenhista. Desenhava tudo a lápis. Realmente, eu era ótimo. Tanto que, depois que me formei, passei a ser sócio do escritório. Deixei de ser desenhista e passei a ganhar muito menos do que ganhava como desenhista, porque eu realmente era importante para tocar os desenhos do escritório. Com o tempo, cheguei a ajudar o Cardozo com alguns desenhos, a finalizar alguns deles.

É preciso falar um pouco da FAU nos anos 60 e 70. Essa idéia, que foi passada para cá, de um ateliê único, e que agora não funciona muito, porque as turmas são muito grandes - cada turma tem 150 alunos - na época funcionava muito bem, porque você circulava por todos seus colegas de todos os anos e via o trabalho que todo mundo estava fazendo. A FAU inteira tinha 100 ou 120 alunos. Por outro lado, você trabalhava em uma prancheta e o professor passava por sua prancheta duas ou três vezes por dia. E o Antunes era uma pessoa simpaticíssima, de um desenho muito livre, muito solto. Ele sentava à sua mesa e ajudava-o a desenhar; colocava cor em seu desenho. Era uma coisa muito entusiasmante. Não cheguei a presenciar isso, mas em algumas turmas os projetos eram passados do seguinte modo: "Hoje vamos fazer o projeto de uma capela. Vocês têm quatro horas para fazer o projeto". Os desenhos eram produzidos naquelas quatro horas e depois colados na parede; discutia-se desenho por desenho.

As turmas eram de 40 alunos - a minha turma foi, excepcionalmente, de 70 alunos, porque, naquele ano, baixou uma portaria na qual todos que tivessem conseguido uma nota acima de cinco (5) no vestibular ingressariam nas faculdades. O Antunes era um cara "boa praça", e em julho do primeiro ano, ele levou a turma inteira para a Bahia. Bom lembrar que, naquela época, a FAU tinha um ônibus e a gente entrava no ônibus e ía para a Bahia, Brasília, Ouro 
Preto. Além disso, todos os fins de semana, alguns professores levavam-nos para ver suas obras. Era um grupinho pequeno. Conhecíamos os colegas, as mães, os pais, os irmãos, as tias. Conhecíamos todo mundo.

No escritório, o ambiente era bastante agradável. $\bigcirc$ Antunes também era uma pessoa que colocava sempre tudo para cima; o Cardozo era uma pessoa fechada em si mesma, trabalhava praticamente sozinho em sua prancheta. Quando havia alguma comemoração, o escritório todo se mobilizava para organizar uma festa. As festas na casa do Cardozo eram muito bem produzidas e era a gente que fazia. A gente parava o escritório para fazer uma festa e fazíamos várias. Era muito gostoso.

Eu tinha pouco contato com obra. Na verdade, eu era um elemento de escritório. $\bigcirc$ Cardozo ficou no escritório até 1971 e depois se mudou para a Inglaterra. Estou dizendo isso porque, só no último ano em que o Cardozo esteve no escritório, vi alguma obra com ele e fui convidado a fazer um banco - o desenho de um banco em um dos projetos. Quebrei muito a cabeça com isso. Foi muito prazeroso fazer um projeto dentro de um projeto, e fui ver o banco executado, e gostei do resultado. Comecei a entender o desenho do Cardozo, que era de uma construção geométrica muito requintada. Naquela época, eu era recém-formado, e era difícil entender que aquilo resultava em uma obra, e pude começar a perceber isso na medida em que fui visitar suas obras e perceber a eficiência daquela geometria. E o Cardozo foi, muitas vezes, criticado por essa construção geométrica rigorosa. Lembro-me dele dizendo que os projetos do Burle Marx também tinham uma geometria rigorosa na construção. É uma outra geometria, mas é também de uma construção elaborada e rigorosa. Mesmo a construção de coisas muito orgânicas passa por uma geometria elaborada. A elaboração é responsável para o sucesso do resultado final.

Por outro lado, quando o Cardozo comunicou sua decisão de mudar-se para Londres, ele começou a preparar o material para levar para a Inglaterra e um outro rapaz e eu trabalhamos nisso, transformando os desenhos técnicos em desenhos mais expressivos, mais elaborados. Fiz questão de conhecer as obras para as quais estava fazendo os desenhos; principalmente, para poder inserir a vegetação nesses desenhos, porque os projetos de plantação do Cardozo eram de volumetria. Eles tinham a especificação de plantas, não em sua totalidade, mas apenas dos elementos dominantes, estruturadores do espaço e, muitas vezes, essa vegetação era mudada na obra. Ele fazia um acompanhamento rigoroso, não só em relação às plantas, mas também em relação à parte construída. Ele tinha seus canteiros prediletos - canteiros profissionais da pedra - e os carpinteiros com quem gostava de trabalhar. Tinha um acompanhamento bastante presente na obra, mesmo na parte de vegetação. Ele saía com o cliente muitas vezes para comprar as plantas. 


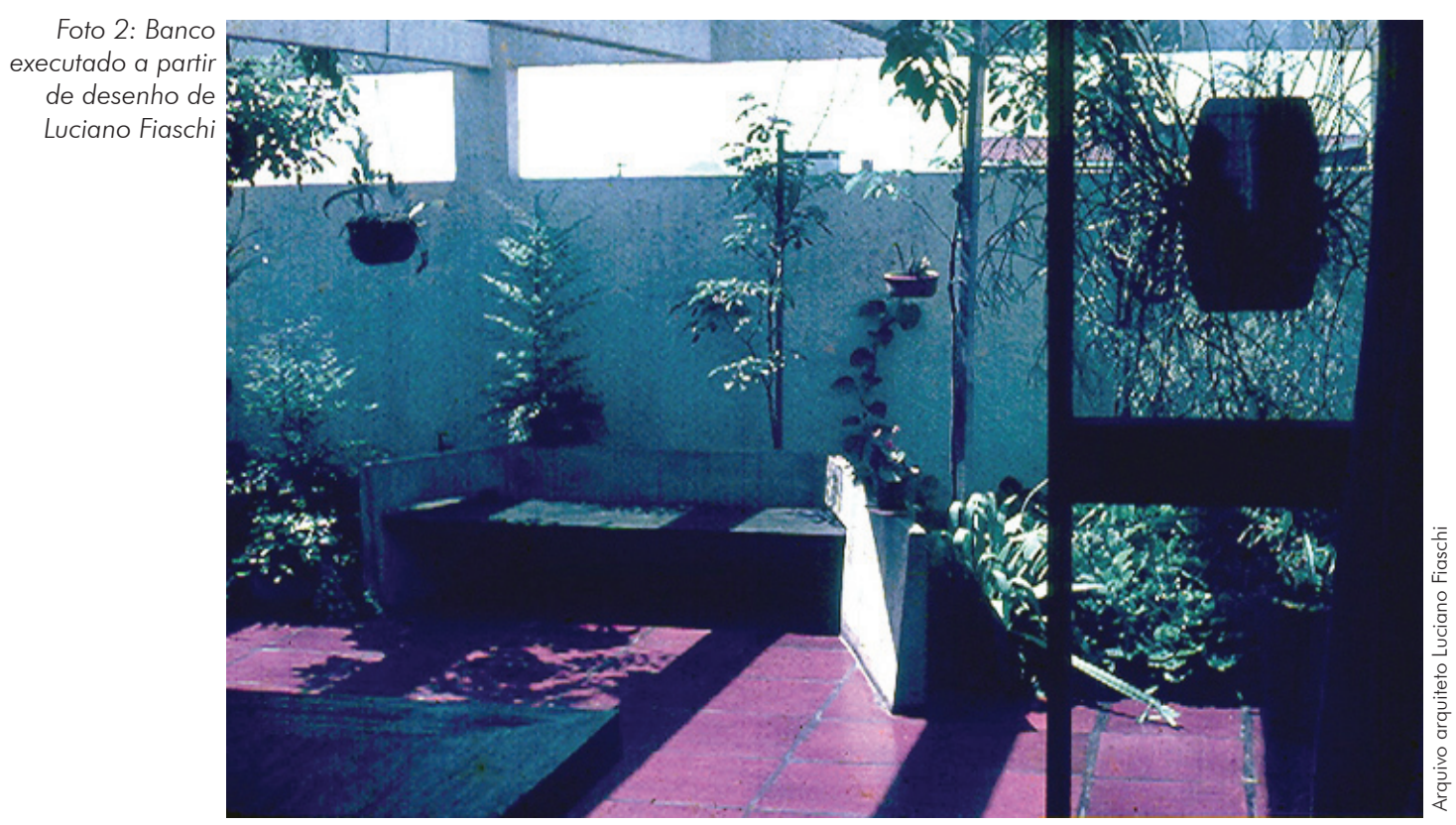

Muita gente dizia que o Cardozo não tinha um domínio grande sobre a vegetação. E não é isso! Acho que o entendimento que ele tinha da vegetação era diferente do que o Burle Marx tinha. É lógico, o Burle Marx era um "botânico" e conhecia tudo sobre as plantas. Mas o Cardozo tinha uma formação de horticultura - seu pai teve um viveiro nos Estados Unidos. Ele sabia transformar uma planta. Se ele especificava uma jabuticabeira para um determinado lugar, que deveria ter uma forma preestabelecida, ele mexia na jabuticabeira para que ela ficasse com essa forma. Ele pendurava pesos, encaixava tábuas entre os ramos para que ela apresentasse uma forma mais aberta, e também tinha o hábito, muitas vezes, de plantar três árvores em uma mesma cova para que atingissem uma forma inusitada, uma forma diferente. Ele utilizava bastante o adensamento, a aproximação de plantas para conseguir determinados efeitos de transparência e de formação de galharia.

Em certa ocasião, ele tinha ido para Londres, voltou, e esteve na casa do Antunes, na Granja Viana... O Antunes tinha uma glicínia que circundava toda a varanda e o Cardozo se propôs a podar a glicínia. Então, ele tirou toda a glicínia da varanda, deitou-a no chão e tentou explicar o que fazia: "Eu conto um, dois, três e podo"; "Um, dois, três e pá". Conseguiu uma forma completamente diferente, valorizando os troncos, a ramificação mais antiga e propiciando a formação de uma ramificação nova. A glicínia ficou com uma forma incrível, dobrou a floração. Isso é uma coisa de conhecimento mesmo, do manejo da planta. Não adianta explicar como ele fez. Era "1, 2, 3, pá"; "1, 2, 3, pá". Tentei fazer isso e não consegui. Deu pra trás, deu cupim.

Mas ele entendia muito bem esse negócio de planta e fazia bolas de papel para encaixar entre a galharia; plantar uma árvore de três metros de altura 
e podar rente ao chão para que ela formasse uma ramificação diferente; plantar bambus completamente inclinados para que os brotos novos nascessem eretos. Cardozo tinha muito esse domínio de como plantar e ele ficava ali, junto ao jardineiro, acompanhando o projeto até o fim - lógico que dependendo da escala. Naturalmente, ele está com bastante idade agora, ele pega um ou dois projetos e vai morar na obra; passa de cinco a seis meses na obra, faz todas as compras e acompanha praticamente toda a montagem do jardim.

Mas eu estava dizendo que, realmente, não tive um trabalho tão próximo, a não ser o tal banquinho. Um pouco antes de viajar, ele estava enrolando um cliente que queria, a todo custo, que ele fizesse o projeto, e quando ele viu que já não dava mais, passou o projeto para mim. E eu disse: "Olha... Não sei". Ele disse que eu era capaz. "Então, você fica com o compromisso de corrigir meu projeto. Vou mandar o projeto via correio para a Inglaterra e você verifica, comenta". E na realidade, não voltou nenhum comentário. Saiu o que saiu. Eu já estava sabendo empregar aquelas curvas e retas. Aquelas coisas todas eu sabia fazer. Não sabia o que acontecia com tudo aquilo, mas tive tempo de implantar e ver o que acontecia. Não sabia muito sobre vegetação, porque, mesmo aqui no curso da FAU, jamais se falou nome de planta. Mas tive um tempinho, entre o anteprojeto e o projeto de plantação da obra, para pesquisar um pouco. Eu já estava fazendo isso com outro arquiteto, Paulo Del Picchia, que foi meu colega de turma e também trabalhava na área de arquitetura paisagística, ambos assessorados por um agrônomo que trabalhava com o Cardozo, Eduardo Haberland, com quem até hoje trabalho.

Nessa época, não existia livro nenhum. Existia aquela coisa, a Exótica, um horror. Existia o "livrinho" do (Harry) Blossfeld, que ensinava a misturar o ipêamarelo com a petrea roxa - que ficava muito legal. Não sei se era a melhor coisa que existia. Ele descrevia a planta, mas não havia fotografia. Então, a gente saía fotografando, tentando identificar, perguntando para as pessoas como é que se chamava isso, como é que se chamava aquilo e fazendo um pequeno fichário de plantas. E, com esse vocabulário de 20, 30 plantas, consegui montar um jardim.

Mais tarde, fiz alguns cursos, comecei a fazer excursões com o pessoal da biologia, com o Leopoldo Coutinho, com a Nanuza (Menezes), com o João Semir, da Unicamp; fiz excursões para a Serra do Cipó e para regiões do cerrado. Chegamos a montar algumas excursões, já pela ABAP, para a llha do Bananal, Pantanal do Mato Grosso, etc. e fomos aprendendo com as discussões e as visitas técnicas. Fiz muitas visitas a viveiros; fiz um curso de taxonomia de Fanerógamos. Se eu contar, ninguém sabe o que é isso. Eu também não sabia, por isso fui fazer. Fiz também cursos de morfologia e fisiologia vegetal na Biologia da USP por indicação da Nanuza, com quem 
já tinha feito algumas viagens. Não foram muito úteis. Eram uns exercícios bonitos em que você seccionava o ovário, contava o número de estames, o número de pétalas e descobria, enfim, qual era a família. Quando eu via a flor, já sabia qual era a família. Eu fazia o caminho inverso e acertava sempre, mas eu enganava. Fazia o curso com a Vera Severo e a gente abalava, porque acertávamos tudo. A gente já conhecia tudo na realidade, mas foi muito bacana essa observação científica da planta.

E comecei a aprender sobre plantas assim, e uma coisa que percebi, e que inclusive ouvi do Burle Marx em uma de suas palestras, é que "nos primeiros projetos, você usa tudo o que conhece e tudo que gosta... Você descobre o nome botânico da planta e acha que conhece a planta...". E eu era assim também. Fazia erros bárbaros. Quando conheci a Spathodea campanulata - que não é uma beleza de árvore, encantei-me com a sonoridade do nome da planta e usei-a muito. $\bigcirc$ engraçado é que conheço muitas pessoas que usam essa planta, porque acham o nome sonoro. Cheguei a usar grupos de quatro ou cinco em residências de lotes urbanos. Elas arrebentaram o piso.

Outra planta que usei muito, a Scheflera, introduzida por volta de 1970, era como hoje o Ficus benjamina, que todo mundo acha que é uma planta de vaso, e é uma árvore enorme, imensa. $\bigcirc$ pessoal põe em um vaso. Daí, enjoa do vaso e coloca no chão, junto à parede. Ela cresce e derruba a casa. Eu também, depois de muito tempo, descobri que era uma árvore. Muito pouca gente já viu a Scheflera como uma árvore, com copa, esgalhada. Isso eu vi no exterior. Acho que tem uma no Parque da Água Branca muito antiga.

Estou há 30 anos na profissão e vejo as minhas coisas de 30 anos atrás e algumas são catastróficas mesmo... Estou corrigindo muita coisa, porque tem muito disso, você vê a foto, sabe o nome, e acha que sabe tudo da planta, e não é bem assim. Hoje, tenho muita cautela em introduzir em meus projetos espécies recém-lançadas. Por exemplo, agora que saiu o tal do Bambu mossô, quando o cliente fala que quer uma coisa bem clean, já sei que ele quer o Bambu mossô. Aquilo cresce, alastra-se. Uma muda, daqui a 20 anos, estará ocupando quase um hectare. Esse tipo de conhecimento a gente precisa ter. Quando uma espécie é introduzida, é usada descaradamente.

Vou falar um pouco de como comecei a depurar, a dominar a escala do projeto: a conhecer a geometria, construir coisas bem estruturadas, procurar um desenho agradável. É muito comum você construir um piso de linhas diagonais e achar que essas linhas conseguem amarrar um muro de arrimo que está lá no fundo. No desenho, essas coisas ficam amarradas, mas, efetivamente, não estão amarradas, não chegam a configurar espaços e acho que esse foi o aprendizado mais lento que tive: o conhecimento da escala; até que ponto você pode elaborar um detalhe, até que ponto você não deve elaborar esse detalhe; o que é o projeto pequeno dentro do projeto grande; 
e isso tive a oportunidade de ver em meus projetos implantados e também nos projetos do Cardozo, ao visitá-los. Cheguei a ver muitos projetos, a fotografar, a ver o Cardozo explicar esses projetos para o "Benê" (Benedito Abbud).

Benedito Abbud fez o Trabalho de Graduação Interdisciplinar (TGI) sobre - Cardozo e o acompanhei nas entrevistas, em que ouvi coisas muitas interessantes: "Cardozo, por que ali você plantou três grupos de três palmeiras?" "Por que elas foram plantadas juntas?" Isso resultou naturalmente em uma curvatura no caule das palmeiras. "Então, por que você fez isso?". Cardozo explicava que, da sala, não se via a piscina. "A piscina está bastante longe de propósito. $\bigcirc$ gramado é que é importante. A piscina está lá longe e você, sentado, não vê a piscina". Para quem conhece os desenhos do Eckbo, a piscina é formada por aquelas duas curvas truncadas, e as palmeiras são uma referência ao desenho da piscina. Você não vê as linhas curvas da piscina, mas vê a curvatura das palmeiras. "Por que você 'quebrou' o caminho e plantou uma jabuticabeira aqui nessa quebra do caminho?" E aí tinha umas explicações muito boas. $\bigcirc$ Cardozo chegou a escrever sobre a luz no projeto, nos espaços abertos: "Você anda mais rápido nas áreas iluminadas e mais lentamente nas áreas nãoiluminadas. Se você está percorrendo este caminho você tem duas quebras - em uma delas está a jabuticabeira. Primeiro você tem uma dimensão do quanto você está andando. Vamos supor que o caminho tenha 100 metros, sendo 30 metros até a jabuticabeira. Você andará primeiro os 30 metros, e depois os 70 metros, porque aquela jabuticabeira é uma ruptura em seu trajeto. A mudança de luz também é uma ruptura em seu trajeto. Você sai do sol pleno e dirige-se para a sombra da jabuticabeira. Você quebra de novo sua velocidade até a jabuticabeira e, além disso, o piso na jabuticabeira é outro. Em um piso liso, você anda mais rápido; em um piso rugoso, você anda mais devagar. Por outro lado, esta jabuticabeira é um ponto focal, para onde você se dirige e aquela quebra prepara você para um outro percurso onde se desfruta de uma outra maneira caminhar". Essas coisas todas você não lê no desenho.

Em uma das ocasiões em que o Cardozo veio para São Paulo, eu o levei a trabalhos que tinha feito e ele me falou uma coisa que não entendi: "Olha que muro bonito! Mas está muito rápido". E era exatamente assim: você corria a vista pelo muro e ele acabava mesmo muito rápido; precisava de alguma coisa que possibilitasse uma visão pausada do muro. É curioso dizer que as aulas do Cardozo aqui na FAU eram assim. Era: "muito rápido", "está furando" ou "não está furando" - ninguém entendia nada. Acho que só depois que começa a trabalhar é que você entende o que é um furo: "sua vista fura", "sua vista não fura". Quando você começa a projetar, a passar por algumas dificuldades, você começa a entender aquele negócio que ouviu há dez anos.

Nas vezes em que fui para Londres, o Cardozo chegava em casa à noite e me dava aulas. A gente se enchia de capotes e saía de casa - eu, ele e um cachorrão. Quem escolhia o caminho era o cachorro e ele arrastava a gente. 
Cardozo ia falando das relações espaciais da cidade, das atitudes do inglês e como a luz trabalha sobre determinadas coisas, e traçando paralelos: "Isso os ingleses adoram fazer. Os franceses falam assim (movimentando as mãos), porque na França tem mais luz e ele faz assim (gesticulando) e a luz brilha na mão. $O$ inglês jamais faz assim, o inglês é mais uma coisa de textura - você vê pelas esculturas do Moore. As mulheres italianas são redondas, peitudas, 'bundudas', porque aquilo funciona na luz e as inglesas não, elas têm a pele toda bonitinha, um cabelo liso, porque isso funciona na luz difusa da Inglaterra". Não sei se é isso, mas o gótico é incrível na Inglaterra, de silhuetas, onde o barroco nunca foi legal. Acho que tem uma certa lógica, e foi muito bacana ouvir isso.

Naquele momento, entendi tudo aquilo que não havia entendido na FAU e em meus primeiros trabalhos - e acho que fui me encaminhando de uma maneira diferente. Continuei a usar o mesmo tipo de desenho, a mesma geometria elaborada, mas já com naturalidade, entendendo aquilo espacialmente, inclusive a vegetação, como um material de construção, de estruturação do espaço e não como um enfeite. Em meu trabalho, toda a cor ficou muito para trás. Acho que vim aprender a usar um pouco de cor vendo os trabalhos do Burle Marx, que eu achava uma coisa periquitíssima, mas não é.

Demorei a aproximar-me dos trabalhos do Burle Marx e a sentir as mesmas qualidades espaciais que sentia nos trabalhos do Cardozo. Fomos conhecê-lo, e ver seus trabalhos. Eu, particularmente, acho que os trabalhos de Burle Marx aqui em São Paulo são pouco significativos. São mais significativos os trabalhos do Rio de Janeiro, de Teresópolis, de Petrópolis e as intervenções urbanas no Rio. Comecei a perceber algo que jamais tinha percebido, uma coisa abstrata: como ele entendia bem a grande escala e o espaço que se constrói.

Quanto à minha formação, aprendi por meio do trabalho com as pessoas. Acho que muito recentemente, mas muito recentemente, há 15 quinze anos, comecei a interessar-me pelos trabalhos do Eckbo e do (Lawrence) Halprin. Minha referência era só o Cardozo, depois o Burle Marx.

Conheci a Rosa (Kliass) e o (Fernando) Chacel no dia em que fui convocado para uma reunião para que se instituísse a Associação Brasileira de Arquitetos Paisagistas (ABAP). Sou sócio-fundador da ABAP e, durante todas as gestões, menos na última e na penúltima, estive envolvido com a diretoria ou em algum trabalho.

Trabalhei com a Suely Suchodolsky, que era minha contemporânea e casada com meu sócio. Fizemos alguns trabalhos juntos. Dei aula durante um ano no Mackenzie, com a Suely Suchodolsky. Demos seis meses de aula e, no sexto mês, eu já sabia que não queria continuar. Agüentei até o fim do ano. Conheci a Eleonora (Seligmann) e a Vera Ilse (Monteiro da Cruz) na época em que trabalhava comigo a Satiko Mascaro, a qual atualmente não trabalha 
mais com paisagismo. Em uma ocasião, fizemos uma equipe e trabalhamos junto: eu, Vera Ilse, Eleonora e a Satiko, para fazer projetos para o Ruy Othake. Conhecia o trabalho didático da Miranda (Magnoli). $\bigcirc$ Jamil (Kfouri) estava começando como eu. $\bigcirc$ Paulo Del Picchia foi trabalhar no Departamento de Parques e Áreas Verdes da Secretaria Municipal do Verde e Meio Ambiente de São Paulo (Depave).

Apoio-me mesmo no trabalho dos arquitetos. De vez em quando, descubro um arquiteto e fico encantado. O último deles foi o Carlo Scarpa, cujo trabalho adoro. Tento trazer as coisas que ele faz para o paisagismo. Conheço o trabalho do Barragán, do (Isamu) Noguchi e dos americanos por meio de livros. $\bigcirc$ Eckbo esteve aqui no Brasil e tive a oportunidade de conhecê-lo. Ele falava muito do Cardozo. Muita gente falava que meu trabalho parecia com o do Eckbo e eu falava: "Mas é?" Então, fui ver se era mesmo e, diretamente, não era; era via Cardozo.

Achei que seria um privilégio trabalhar com o Paul Friedberg. Trabalhamos juntos, Rosa e eu. Foi bacana conhecer o trabalho dele, embora não tenha sido legal trabalhar com ele.

Em 1987, já tinha uma experiência de trabalho com a Rosa e já tinha feito alguma coisa com o Benedito Abbud também.

"Benê" começou estagiando no escritório e houve alguns momentos em que estive bastante apertado e cheguei a passar alguns trabalhos para ele. Fizemos outros juntos, mas aí já foi na KRAF (Kliass, Re, Abbud, Fiaschi Planejamento Ambiental Ltda.).

Fui chamado para trabalhar com a Rosa no Parque da Lagoa do Abaeté. Era a época em que estávamos trabalhando em relatórios de impacto ambiental, e nós, justamente, montamos a KRAF para fazer esse tipo de trabalho, de escala maior, que envolvesse problemas ambientais. Não deu certo, porque realmente queríamos fazer esses estudos de impacto ambiental bem-feitos, mas não somente como trabalho burocrático, de documentação junto aos órgãos públicos. Quando chegava um projeto para fazermos o relatório, exigíamos que aquele trabalho tivesse qualidade para que passasse bem na Secretaria do Meio Ambiente. $O$ projeto chegava, a gente trabalhava com o autor do projeto para que fosse melhorado, que tivesse qualidade. A gente convencia o dono do empreendimento de que ele não poderia ter 200 lotes; que para ter qualidade, teria de ter 150 lotes. Isso voltava para o arquiteto, autor do projeto. Ele revia o projeto em cima de questões clássicas, como mapeamento da declividade, vegetação significativa... A gente chegou a formar um grupo de consultores excelentes, com geógrafos, geólogos, profissionais de sistema viário e transportes, recreação e turismo. É lógico que um trabalho desses demora. Primeiro, o cliente precisava concordar em perder os tais lotes e se convencer que teria um loteamento melhor. 
Um dos primeiros trabalhos da KRAF foi o Panamby. Passaram-se dois anos e a gente estava pagando para concluir os trabalhos.

Chegamos a fazer estudos bem interessantes. Um deles era um trabalho de preservação do potencial turístico de três cidades de Santa Catarina, no Vale do Rio Negro: Rio Negrinho, São Bento do Sul e Vista Alegre, ou coisa assim. Rio Negrinho produzia móveis em estilo rústico; São Bento do Sul tem fábricas de porcelana. São cidades que não necessitam do turismo, mas têm um grande potencial para isso. Têm matas de araucária, e um sistema de estradas do tempo da colonização alemã, com uma arquitetura alemã maravilhosa daquela época. Fizemos um trabaIho de levantamento com uma equipe de Curitiba, a Aresta, com foto, plantas, cortes e fachadas de toda a arquitetura significativa da região. Havia cemitérios da época da colonização alemã. Um potencial incrível que precisava ser preservado. Fizemos um trabalho para mostrar esse potencial e, com os técnicos de recreação e turismo do Serviço Social do Comércio (SESC), decidir qual o tipo de turismo adequado para a região. Um turismo regional? Um turismo internacional? Aproveitamos o potencial industrial da região e sugerimos um turismo de eventos ligado à economia - produção industrial, feiras de gado, feiras de móveis e coisas assim. Foi um trabalho muito interessante, feito com representantes das três cidades. Fizemos também levantamentos de vegetação e de arquitetura e um estudo de acessibilidade. Havia equipe de demógrafos para ver como as populações iriam crescer. $\bigcirc$ trabalho foi feito para a SEDUMA, uma secretaria estadual de Santa Catarina que faz esses projetos e encaminha-os para as outras secretarias. Foram elaborados estudos de projetos dos núcleos centrais para aquelas cidades.

Rio Negrinho é uma cidade curiosíssima, na qual havia uma grande indústria moveleira. A cidade se formou ao redor dessa indústria, que faliu, foi demolida e formou um grande vazio, um "central park" na cidade. Esse trabalho serviu para resolver qual o destino daquela grande área: um parque. Elaboramos um estudo para mostrar o potencial daquela área não só como parque, mas como uma área institucional.

Eu aprendi muito com a Rosa, como pegar áreas e programas, destrinchar e chegar ao projeto. A Rosa sabe criar projeto onde não há projeto. Ela mostra para o cliente que é preciso fazer um projeto; inventa o projeto e o projeto faz sentido. Aprendi também o manejo do projeto, o trato com o cliente e a postura ética. Já vi a Rosa pegar um projeto importante, o cliente falar: "Ah, Rosa! Aqui você pega e faz assim", e ela responder: "Ótimo! Você já sabe tudo. Eu te indico um bom desenhista e você faz junto com ele; porque eu não acho nada disso." Depois que se tem 50 anos a gente tem o direito de ser ranzinza, de mandar o cliente "plantar batatas". 
Parque do Abaeté foi um projeto realizado a partir de um convite que a Rosa recebeu de arquitetos baianos. Era um projeto complementar ao de arquitetura. A Rosa iniciou o projeto e fomos para a Bahia. Eu, particularmente, não gostava dos elementos arquitetônicos do projeto, mas conseguimos mudar um pouco o jeito dele.

A Lagoa do Abaeté era uma área que estava invadida por população de baixa, média e alta renda - dentro do parque tinha até casa com piscina. Então, o Antônio Carlos Magalhães falou: "Derruba tudo! Põe todo mundo para fora!" E pagou não o valor do terreno, mas o valor da construção. Marcava um dia: "Você sai no dia quinze do mês que vem". Na data marcada, havia um caminhão para fazer a mudança na porta do morador. Foi de uma coragem muito grande. E precisava entrar com um projeto muito forte, não podia ser só um projeto para ajeitar as dunas, senão as pessoas iriam reclamar.

Essa área de interesse turístico no entorno da lagoa recebeu equipamentos pesados. Foi preciso alocar 300 baianas de acarajé, 300 vendedores de coco, porque você não podia tirar essa gente de lá. As próprias lavadeiras não poderiam mais lavar roupa, por causa do sabão, que contribuía para a polvição das águas. No entanto, foi permitido que elas continuassem a estender as roupas na lagoa, mas como não poderiam mais lavar a roupa lá, foi feita uma lavanderia pública para elas.

Eu já participei de vários projetos e sempre tem muita pressão. É a mãe de santo que faz seus despachos no terreno, é o jogador de futebol que passa a exigir um campo, uma sede, sanitários e mais vestiários. No Abaeté, trabaIhava em um lugar no qual havia filas para negociar o valor dos imóveis e o pessoal, quando soube disso, começou a arrumar o muro da casa, porque eles ganhariam em cima das benfeitorias do terreno. Eles não começaram a demolir as casas, começaram a construir a toda para o governo pagar. Isso aconteceu no Pelourinho também. Foi um projeto implantado em tempo recorde. Não posso reclamar da implantação, tudo foi plantado, mas tudo foi destruído. Não houve uma continuidade; inaugurou direitinho, fez-se a festinha e tudo se acabou. É assim em todas as nossas praças e em todos os nossos parques. É assim sempre! $\bigcirc$ chafariz funcionou até o dia da inauguração. Há trabalhos muitos bem-executados, como o projeto da Rosa para a frente da Sala São Paulo - um trabalho de execução impecável. Está destruído. Recentemente, também, foi inaugurado o Parque de Juventude, com uma implantação impecável. É o primeiro parque que vejo com irrigação automática, iluminação em pés de árvores e árvores já plantadas com quatro, cinco metros de altura. Quanto tempo isso vai durar?

Parque do Panamby nunca foi implantado de acordo com o projeto, foi parcialmente executado. O escritório do Burle Marx foi convidado pela KRAF para fazer o núcleo central, recuperando um projeto do próprio Burle Marx, 


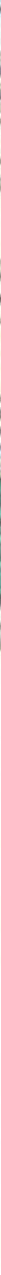

Foto 3: Perspectiva da proposta para a Lagoa do Abaeté. Desenho: Valandro Keating. Arquivo arquiteto Luciano Fiaschi

da década de 50. Esse núcleo foi melhor implantado. Fizemos o projeto da área de mata, do entorno, mas esse foi precariamente executado. Depois de um tempo, o Paul Friedberg, que veio para dar uma consultoria, disse que queria participar do projeto do parque. Delimitamos a área de parque e conseguimos manter toda a área de vegetação significativa e, dentro dessa área, preservamos o trabalho do Burle Marx. Até hoje, estamos fazendo trabalhos para o parque. Estamos fazendo um projeto para a área dos lagos e, com a Maria Cecília Gorski, projetos para os playgrounds.

Acho que foi o primeiro parque implantado e mantido pela iniciativa privada. $\bigcirc$ empreendedor conseguiu um contrato com a prefeitura para gerenciar o parque durante 20 anos, sendo ele quem sustenta o parque. Foi criada uma fundação, a Fundação Aron Birmann, para implantar o parque. Naturalmente, essa fundação precisou levantar verbas para a implantação.

Vocês sabem que não fomos Rosa e eu que fizemos bordaduras de pingo de ouro... A empresa que iniciou a implementação do projeto, a Lubeca, faliu no meio do caminho e implantou qualquer coisa. Não tinha iluminação, instalaram qualquer coisa; mudaram os pisos todos e trocaram os equipamentos. Além disso, houve uma pressão terrível do Depave: "Oh! Derrubou isto aqui, então, tem de plantar mais quinze!" E não tinha lugar para plantar, 


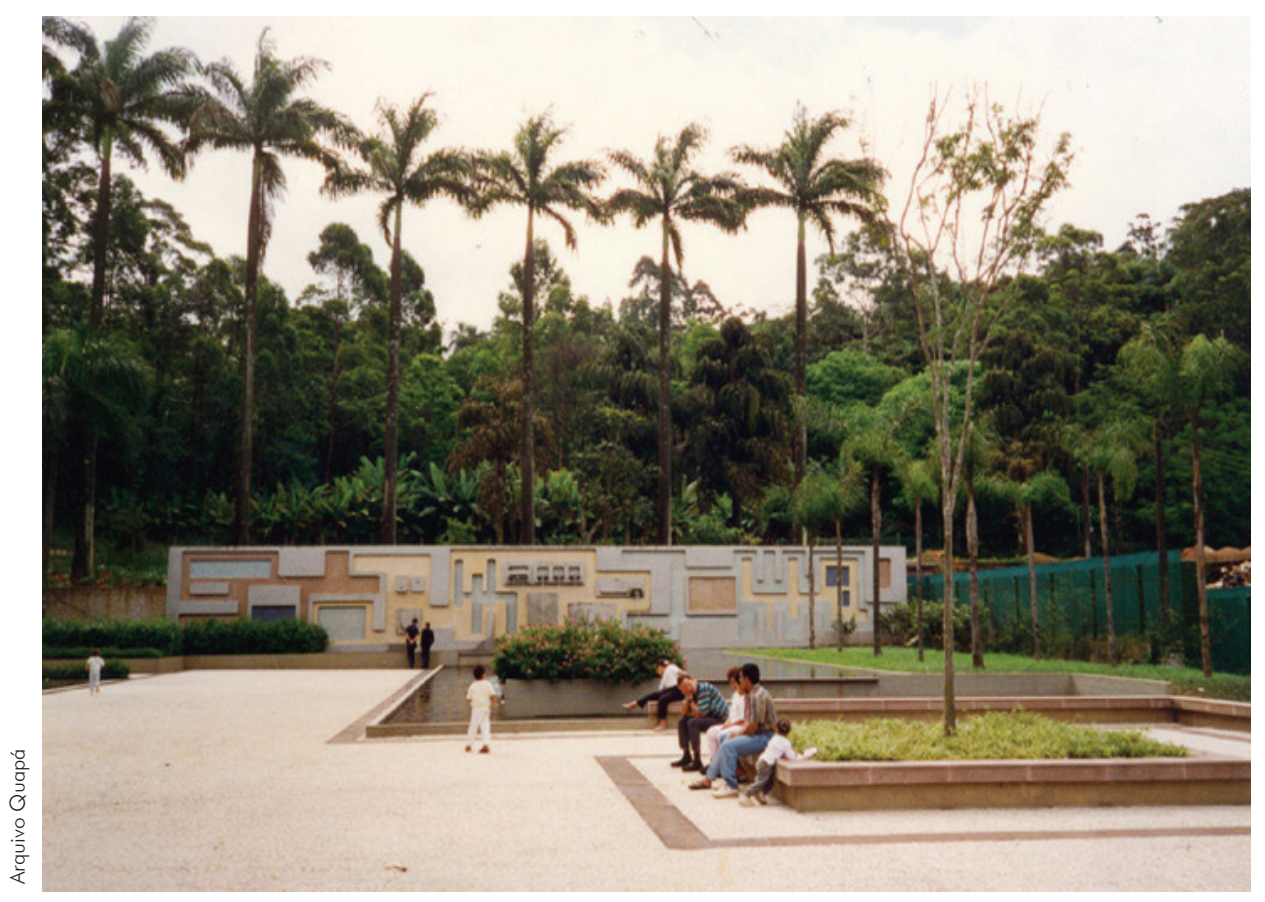

Foto 4: Parque Burle Marx (Panamby) - área recuperada do projeto original de Burle Marx

porque era muito denso. Você traz qualquer coisa lá da mata e planta na área tal e sabe que está demais. No momento, estou reflorestando uma área, na qual é preciso plantar árvores de dois metros em um eucaliptal, sendo $70 \%$ espécies clímaxes, como a peroba. Além de ser um absurdo plantar embaixo de eucalipto, não existe essa quantidade de plantas no mercado. Ou deixa o eucaliptal, que é bonito, ou derruba e faz uma mata. $O$ plano diretor para a região definiu, nos lotes dos edifícios, áreas non aedificandi. Foi um trabalho da KRAF, com o Jorge Wilheim e o escritório do Gasperini (Gian Carlo). E isso é o mais importante: ter criado o parque que está lá, com o potencial que ele tem, mesmo sob pressões fortíssimas.

Em relação às áreas de proteção ambiental, estou trabalhando em um projeto residencial, em loteamento no Guarujá. Como os autores do projeto de loteamento não atenderam à legislação, fizeram um acordo com o Departamento Estadual de Proteção de Recursos Naturais (DPRN) e tiveram de comprar lotes para compensar. Eles permitem que você use apenas 30\% de cada lote. Imagine o milionário que compra um terreno de 1.000 metros quadrados e só pode ocupar 300. Seu gramado, sua casa, sua piscina só podem ocupar 30\% do lote. Impossível! Então, seu projeto tem de entrar no DPRN. Primeiro, chama-se o arquiteto: "Tira a varanda e manda só a planta baixa; a piscina você diminui e junta à casa; e a garagem, que é para cinco carros, a gente diz que é só para um, e consegue-se chegar aos 30\%". Faço um projeto paisagístico e um projeto para entrar no DPRN. O cliente faz uma negociação com o DPRN e constrói aquilo com o tempo. As entidades ambientais criam dificuldades e vendem facilidades. 
Foto 5: Parque Burle Marx (Panamby) - Projeto KRAF

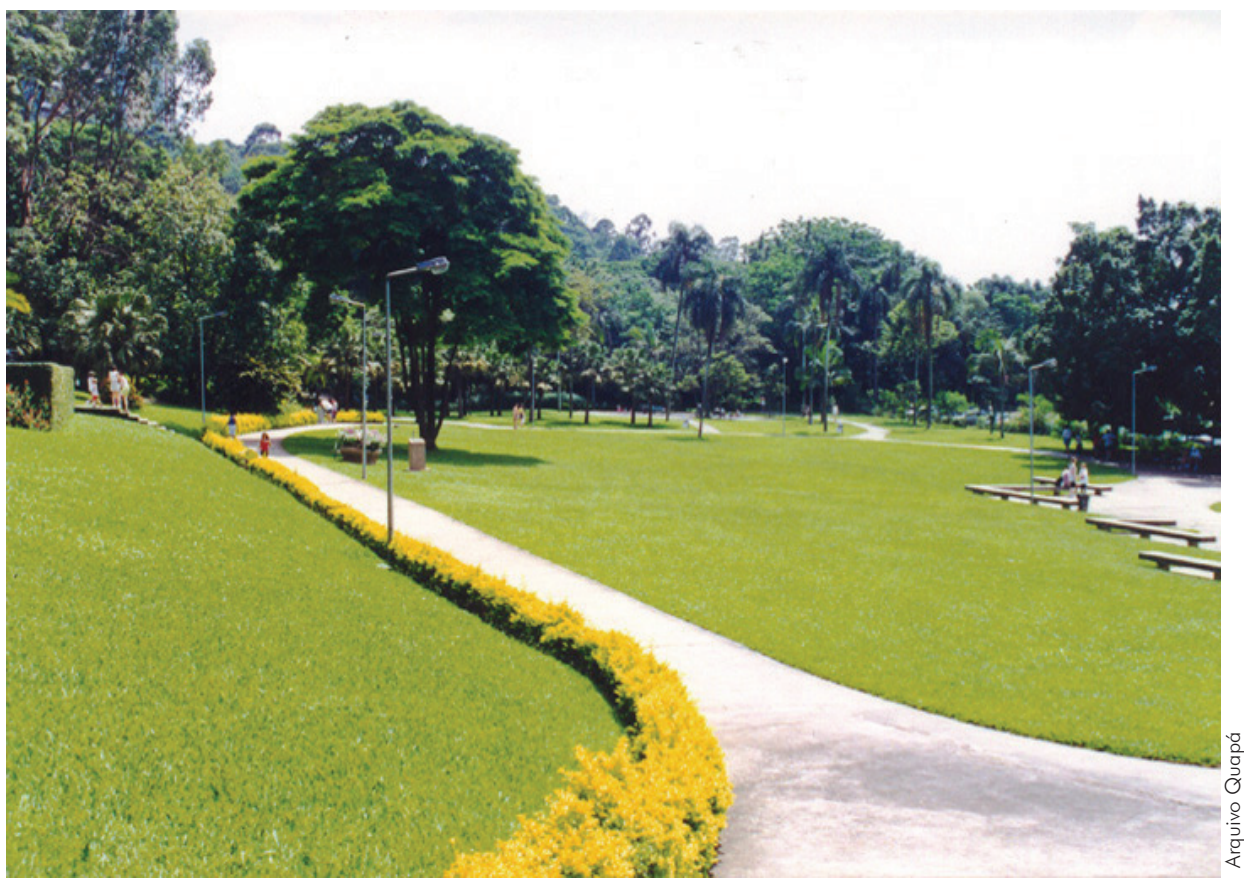

Estou encantado com o trabalho do Peter Walker e vejo alguns arquitetos fazendo aquelas fileiras de buxinho... Eu gosto, mas não é o que faço. É lógico que incorporo alguns elementos que servem de inspiração para meus projetos. Eu ainda vejo muito mais trabalhos de arquitetos do que de paisagistas.

Uma arquiteta de uma construtora perguntou-me se eu tinha experiência em jardins franceses. Falei que não tinha e não queria ter, que achava uma coisa horrorosa. Um outro colega foi lá e fez. Já houve cliente que me perguntou se eu fazia jardim em estilo colonial. "Faço!" Eu faço qualquer coisa e digo que é colonial. Eu já cheguei a fazer jardim para casa em estilo colonial e não existe jardim colonial. Já tive cliente que questionou: "Isso não é jardim colonial, mas ficou bem legal!" Então, eu disse: "Ótimo!".

Quando o cliente é bacana, tudo bem, mas, quando é um chato, eu "chuto o pau da barraca". O que acho muito legal e tenho feito é trabalhar com determinados arquitetos, como o Jorge Bonfim de Santo André - e o primeiro trabalho que fiz com ele, em 1971/72, com o Antunes, foi a casa do Pelé. Comecei a trabalhar com ele em projetos de edifícios residenciais, sendo chamado desde o primeiro traço. Nessa época, não existia guarita, não existia gradil, nem essas besteiras todas, como sala de massagem tailandesa. Nem piscina existia. A gente fazia jardim. Ele me deu a oportunidade de trabalhar com ele e até hoje trabalhamos juntos. Ele faz o primeiro estudo, discutimos em cima e eu conquisto áreas para o jardim. Ele já incorporou isso.

Com outros arquitetos mais recentes, em projetos residenciais, implanto a casa no lote e chego a trabalhar o projeto de arquitetura em seu aspecto volumétri- 


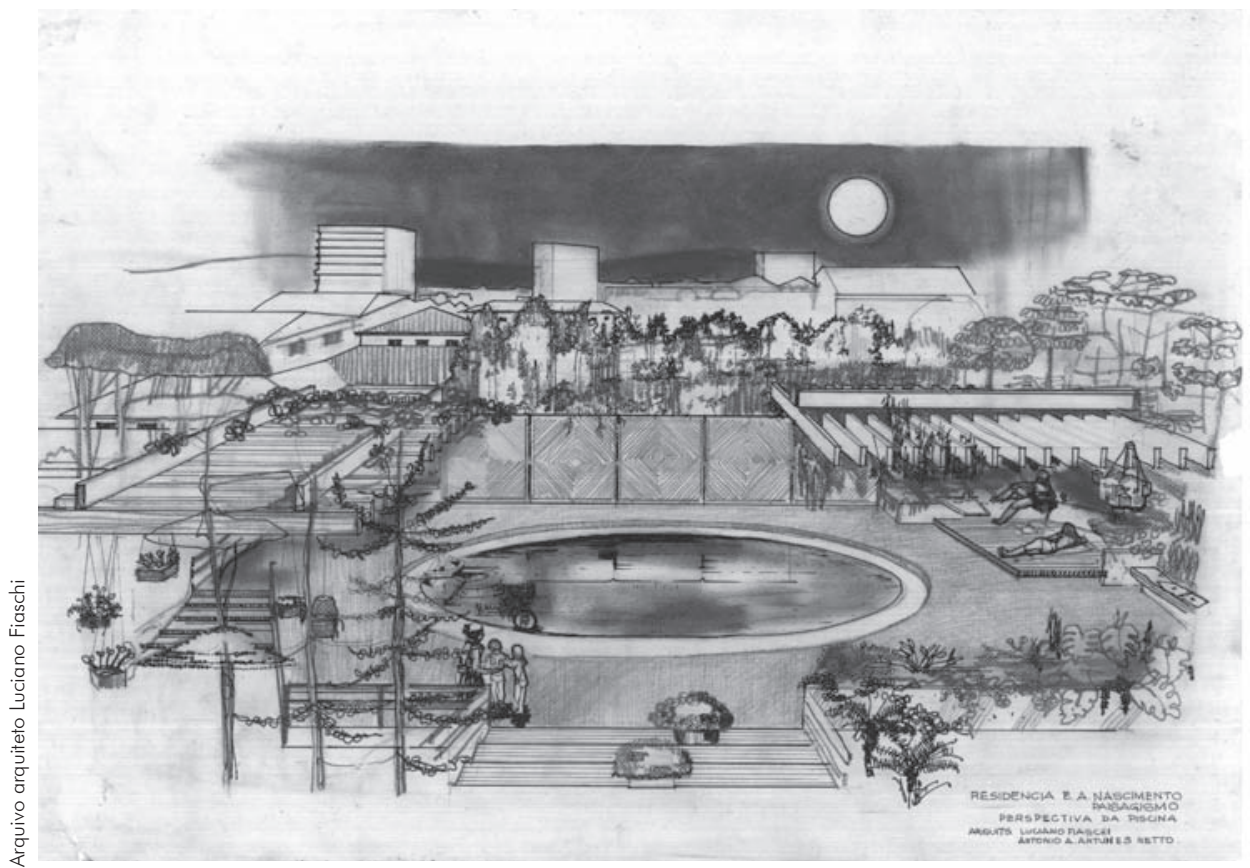

Foto 6: Detalhe da perspectiva do projeto para a residência de Edson Arantes do Nascimento ("Pelé") Projeto de Antonio Augusto Antunes e Luciano Fiaschi

co. Participo do trabalho que antecede o projeto de paisagismo propriamente dito com um estudo da volumetria da arquitetura no terreno. Há muita gente que não sabe projetar em terreno inclinado, então, modelo o terreno para essas obras. Gosto muito de dar consultoria a projetos que podem ou não ser realizados. Vejo que as pessoas têm dificuldade em ler a declividade do terreno e, muitas vezes, transformo completamente os projetos.

Acompanho, freqüentemente, as obras. E isso é importante. $\bigcirc$ fato de estar na obra não garante que ela dê certo. Tenho obras em Criciúma, no sul de Santa Catarina. Eu ia de avião até Florianópolis e viajava quatro horas de carro para chegar lá e essas obras ficaram bem executadas. Acho fundamental, tanto acompanhar a obra como envolver o cliente; ensiná-lo a ler e a entender o projeto. Isso o Cardozo fazia muito bem e vários de seus clientes tornaram-se paisagistas - íam juntos comprar plantas, escolher o piso... O cliente ficava encantado. É importante envolver o cliente. Eu tenho projetos bem executados à distância, porque o cliente se envolveu. $\bigcirc$ cliente se empenhou. Quando o cliente entende, pode até trocar o material. Se for mudar a árvore, ele vai saber que tem de ser uma árvore redonda, de copa baixa, etc. Com o tempo, a gente vai aprendendo a reconhecer o cliente que merece e o que não merece o acompanhamento da obra.

Estou fazendo um condomínio em São José do Rio Preto muito sofisticado. Foi a primeira vez que fui submetido a um consultor de mídia - desses que falam que precisa ter isso, ter aquilo, ter não sei o que lá. Primeiro, ele não se encantou comigo, porque não estou na mídia e ele precisava de uma grife. Depois, ele me apresentou um projeto norte-americano já pronto que 


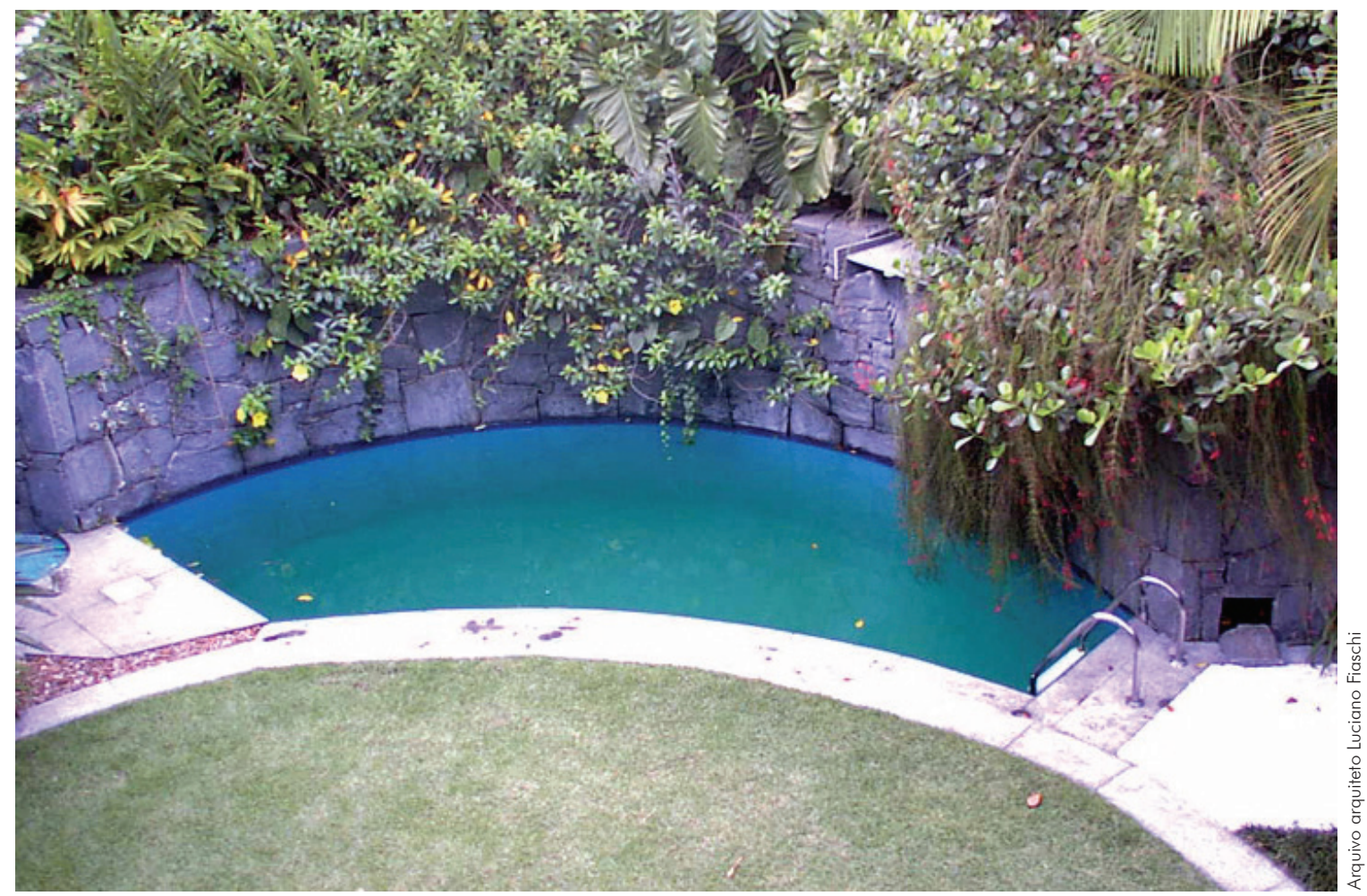

Foto 7: Residência Scatena. São Paulo

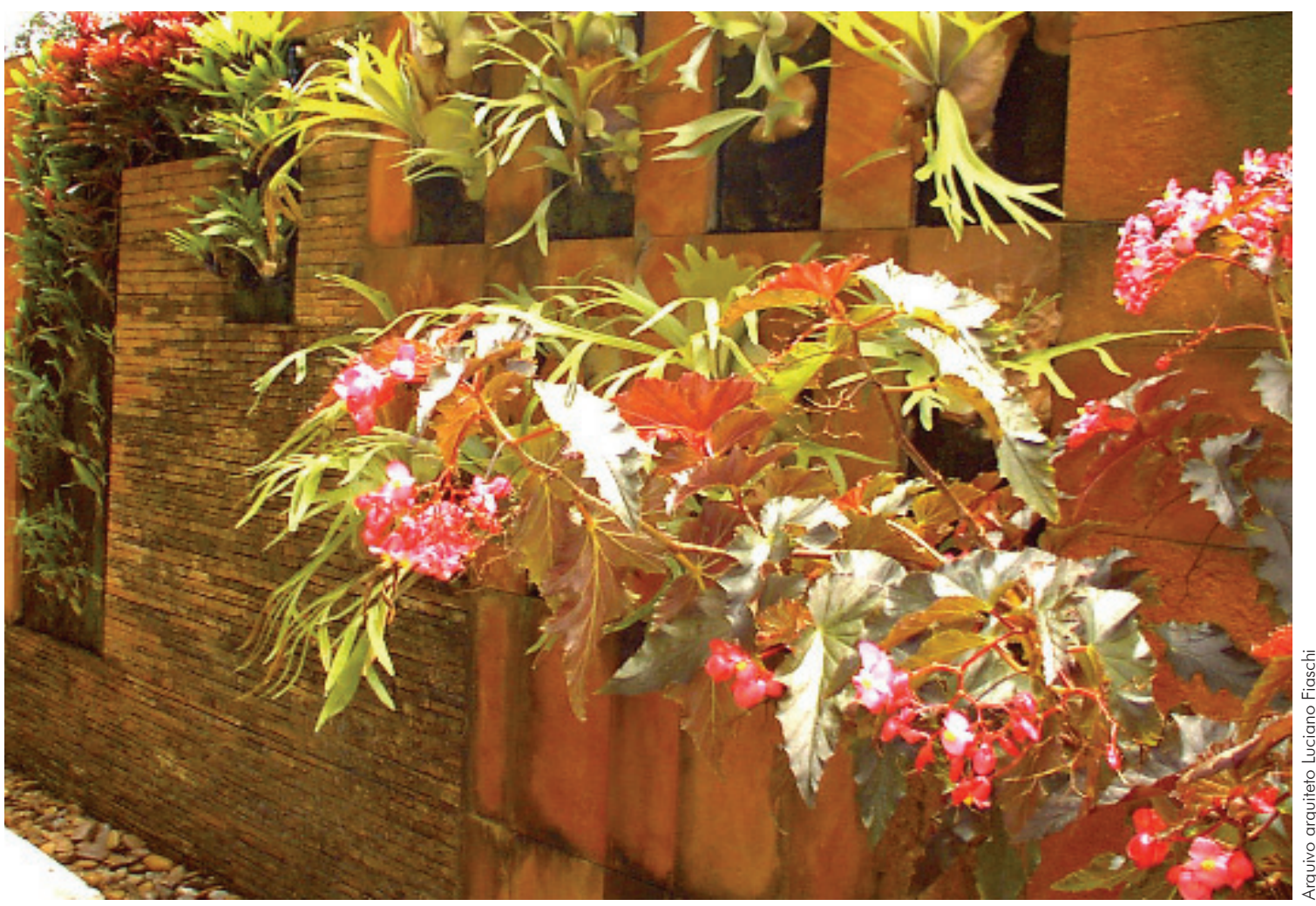

Foto 8: Residência Maria da Graça Zillo. São Paulo 


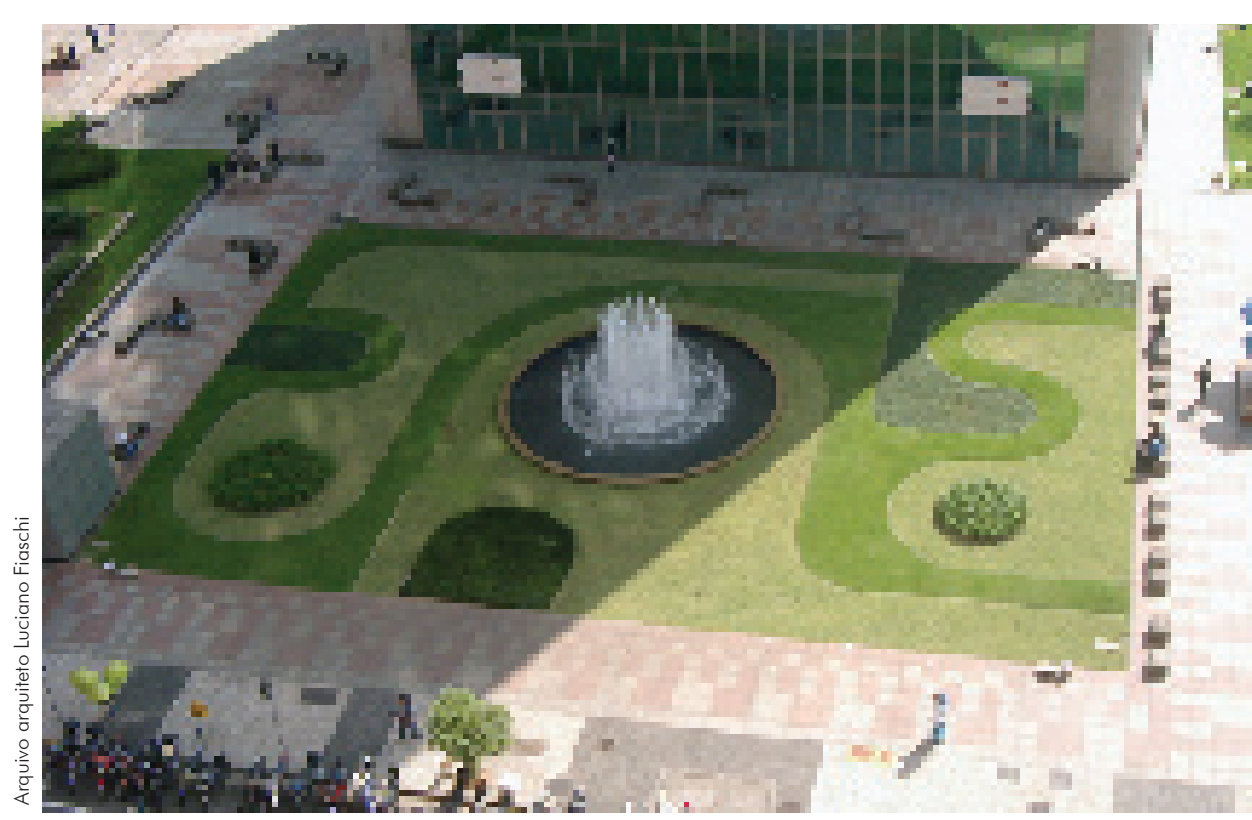

me recusei a desenvolver. Aí, ele olhou meu projeto e disse que estava muito bom, que eu era um artista, e complementou lamentando eu estar fora da mídia. Achei ótimo!

Desde que os térreos de edifiícios residenciais viraram "Disneylândia" acabei ficando um pouco fora do mercado. Na realidade, tenho dois ou três clientes para quem trabalho e não me recuso a fazer o projeto do térreo. Os clientes que me procuram, como o pessoal de Santo André, têm um público certo - não precisam de uma grife.

Fiz prédios sem piscina e sem playground, somente com jardim, e ficaram muito bons. Mas agora tem a questão da segurança, que temos de atender, sem dúvida nenhuma. Aquela coisa pavorosa de trancar as pessoas antes delas entrarem é inevitável. Nesse ano que passou, tive a oportunidade de rever meu primeiro projeto de edifício residencial - que estou refazendo agora, depois de 30 anos, porque a construtora era ruim e a palmeira cresceu a tal ponto que estava rompendo a laje. É um conjunto de prédios de classe média e apareceu uma arquiteta dizendo: "Mas que falta de imaginação. Os prédios de hoje têm champagnerie. Eu vou trazer uns folhetos para você". Disse a ela que conhecia muito bem os folhetos e não ganhava dinheiro para fazer aquilo. Eles não tinham nem dinheiro para trocar o piso, para que fazer esse tipo de coisa? Tenho feito poucos projetos para edifícios, pois têm um preço baixo e não é o que gosto de fazer. Por outro lado, coloco coisas que considero qualidade de alto padrão. Estou conseguindo trabalhar com a Isabel Ruas, introduzindo seus mosaicos em meus projetos. Talvez eu não use o mármore ou travertino romano, que são o padrão, mas consigo colocar a Isabel para fazer um bom trabalho e a Esther Stiller, para a luminotécnica. Acho isso muito mais chique. 
Sou muito influenciado pelos bons artesãos. $\bigcirc$ Cardozo já tinha, na época, - Manoel Cabete, que foi o primeiro a empregar a ardósia em São Paulo; o primeiro a ir para Sete Lagoas buscar ardósia; o primeiro a ir para Pirinópolis buscar pedra-goiás de qualidade. Era um artesão da pedra. Quando você sabe que existe um profissional que faz bem seu trabalho, você começa a especificar o material e a ver suas possibilidades. Atualmente, estou com um profissional da região de ltu, que trabalha peças de granito rosado imensas e estou explorando as possibilidades desse material. Às vezes, conhecendo alguém que trabalha bem a madeira, a pedra, que é um profissional competente, você acaba usando mais esse material, propondo algo além, explorando, divertindo-se.

Agora, estou participando do novo projeto da avenida Paulista. Todo mundo sabe que tem muita propaganda, muita banca de jornal. E não dá para tirar. São compromissos assumidos pela prefeitura.

Na realidade, o projeto da avenida Paulista não é meu, é da Rosa. Estou dando uma consultoria; não estou projetando. Estou tendo a oportunidade de trabalhar pela primeira vez com o (João Carlos) Cauduro e com a Esther, com quem eu havia trabalhado. Sobre as possibilidades da Paulista, acho que iluminação é o ponto forte. $\bigcirc$ piso, de mosaico português, é um piso muito bom, que funciona. Temos de aprender a preservar o que é bom. A Paulista não precisa ter vegetação alguma. Por que ficar construindo floreira, já que o subsolo da Paulista não permite o plantio de árvores? Pelo menos $70 \%$ das calçadas estão comprometidas com tubulações. $\bigcirc$ que dá para plantar no chão, planta-se.

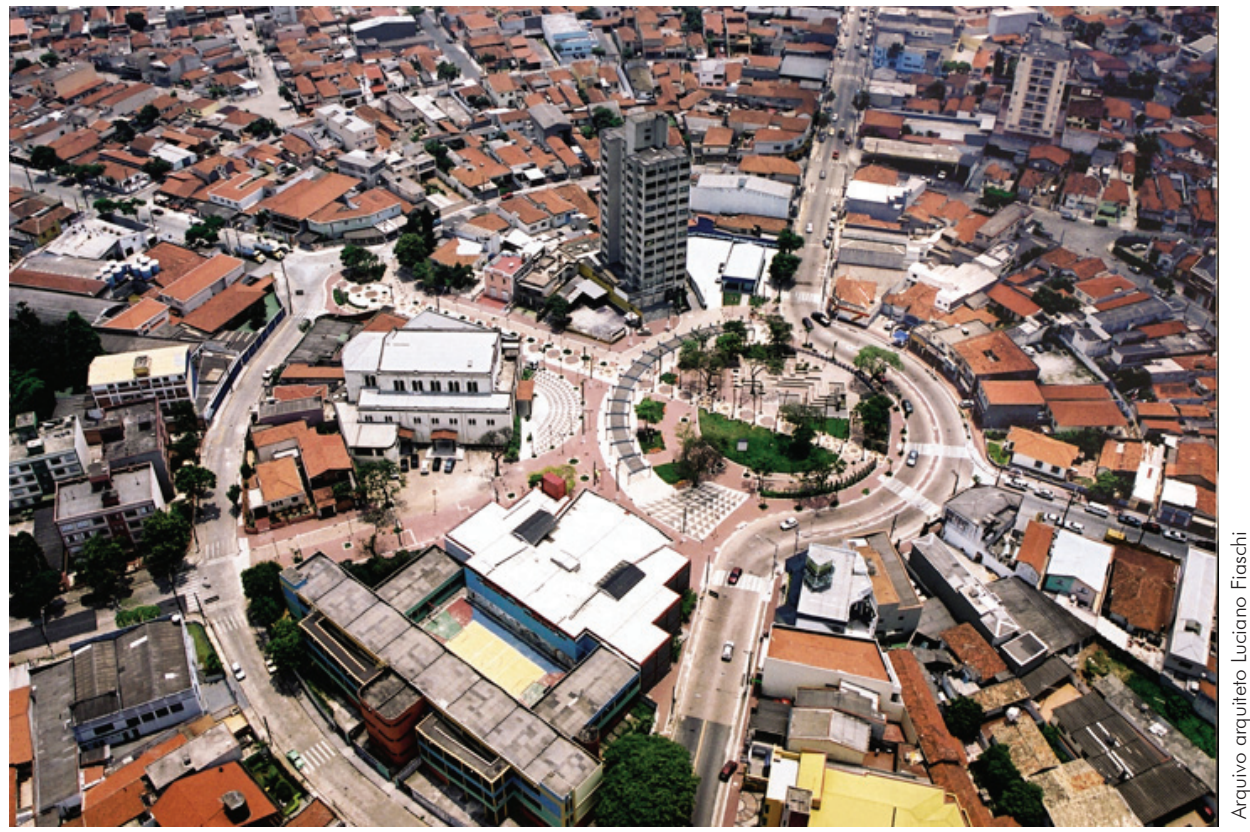

Foto 10: Foto aérea da praça Rui Barbosa. Santo André 


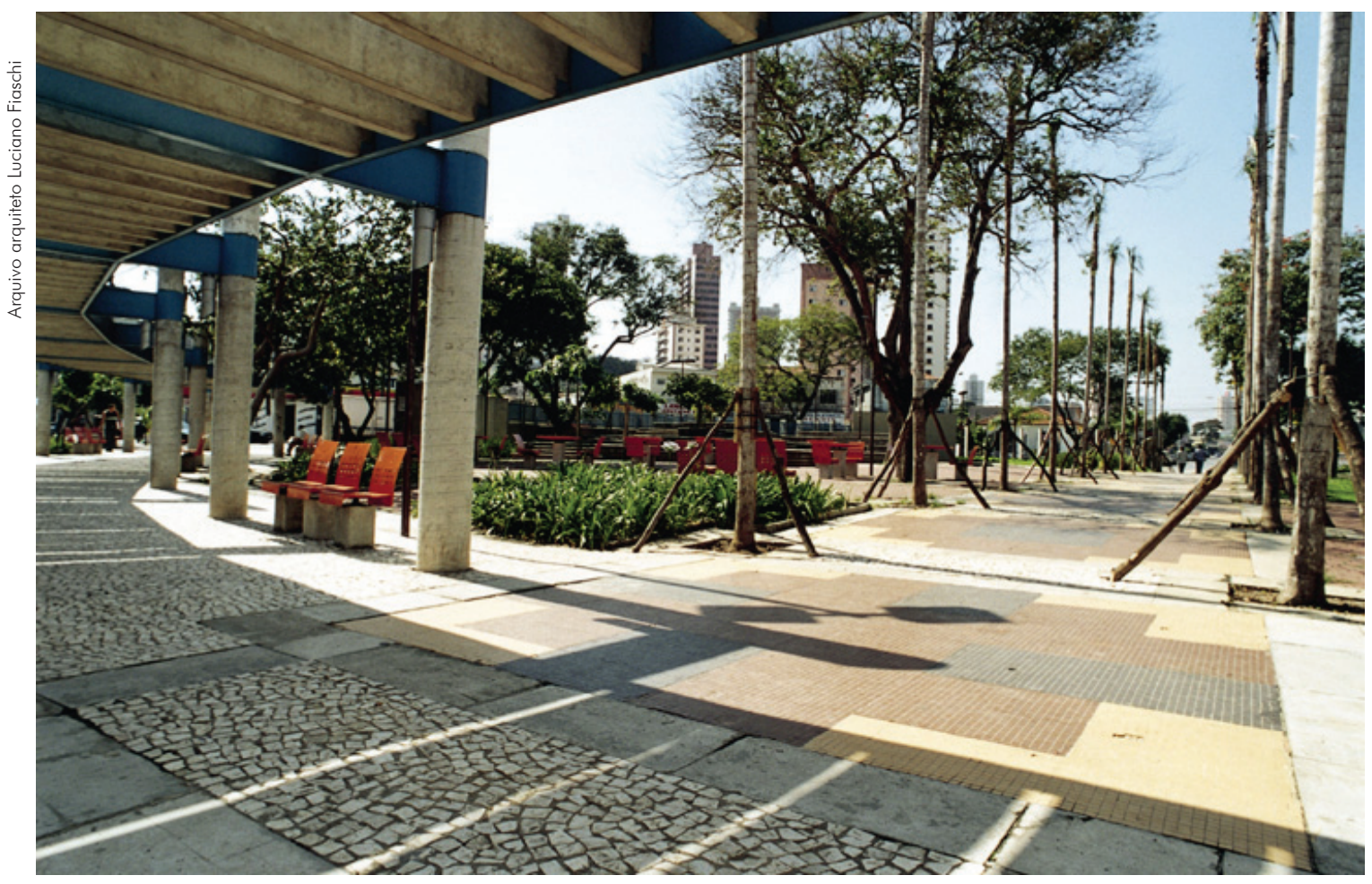

Foto 11: Praça Rui Barbosa. Santo André

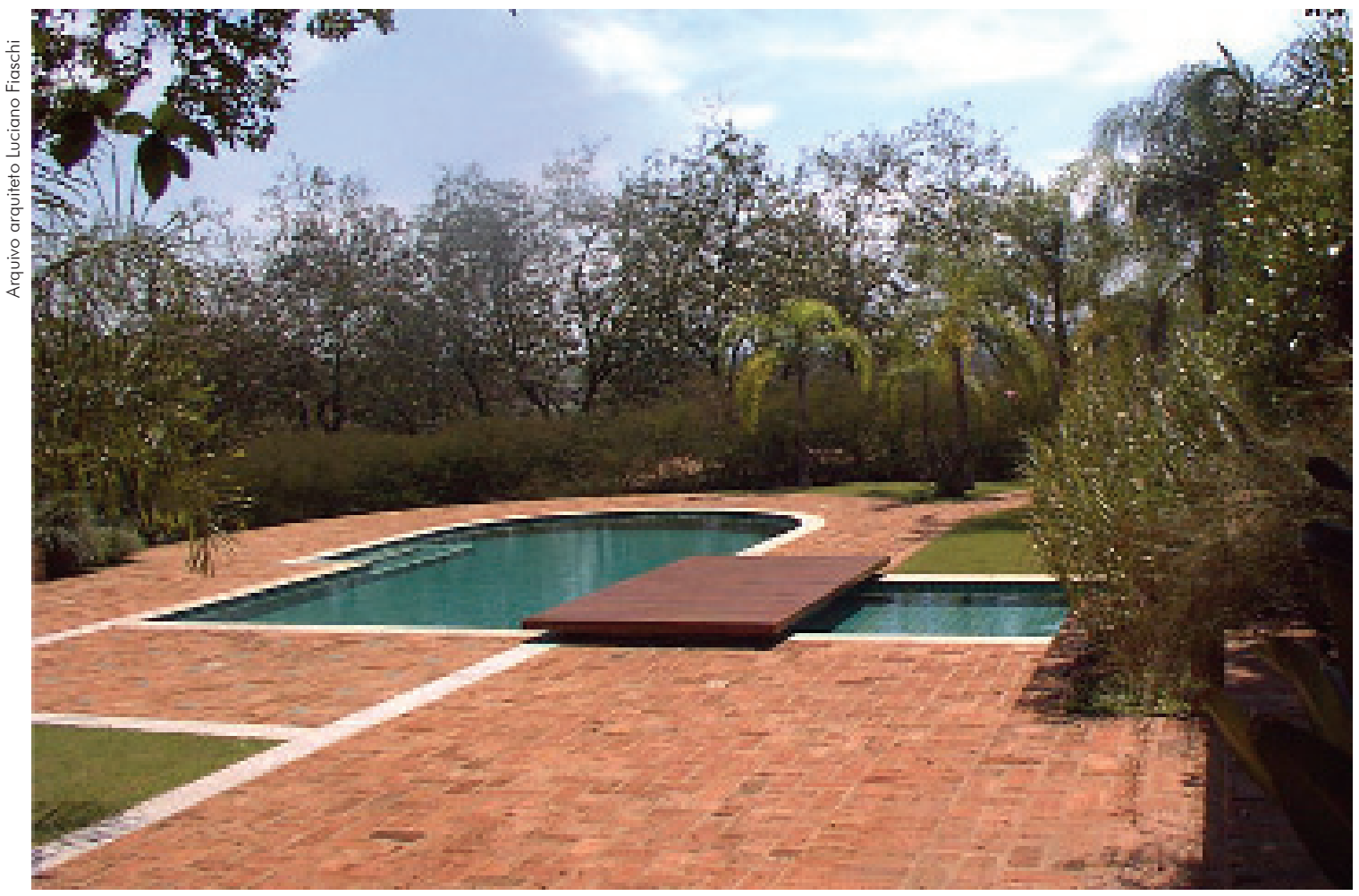

Foto 12: Fazenda Itaúna. Macatuba 

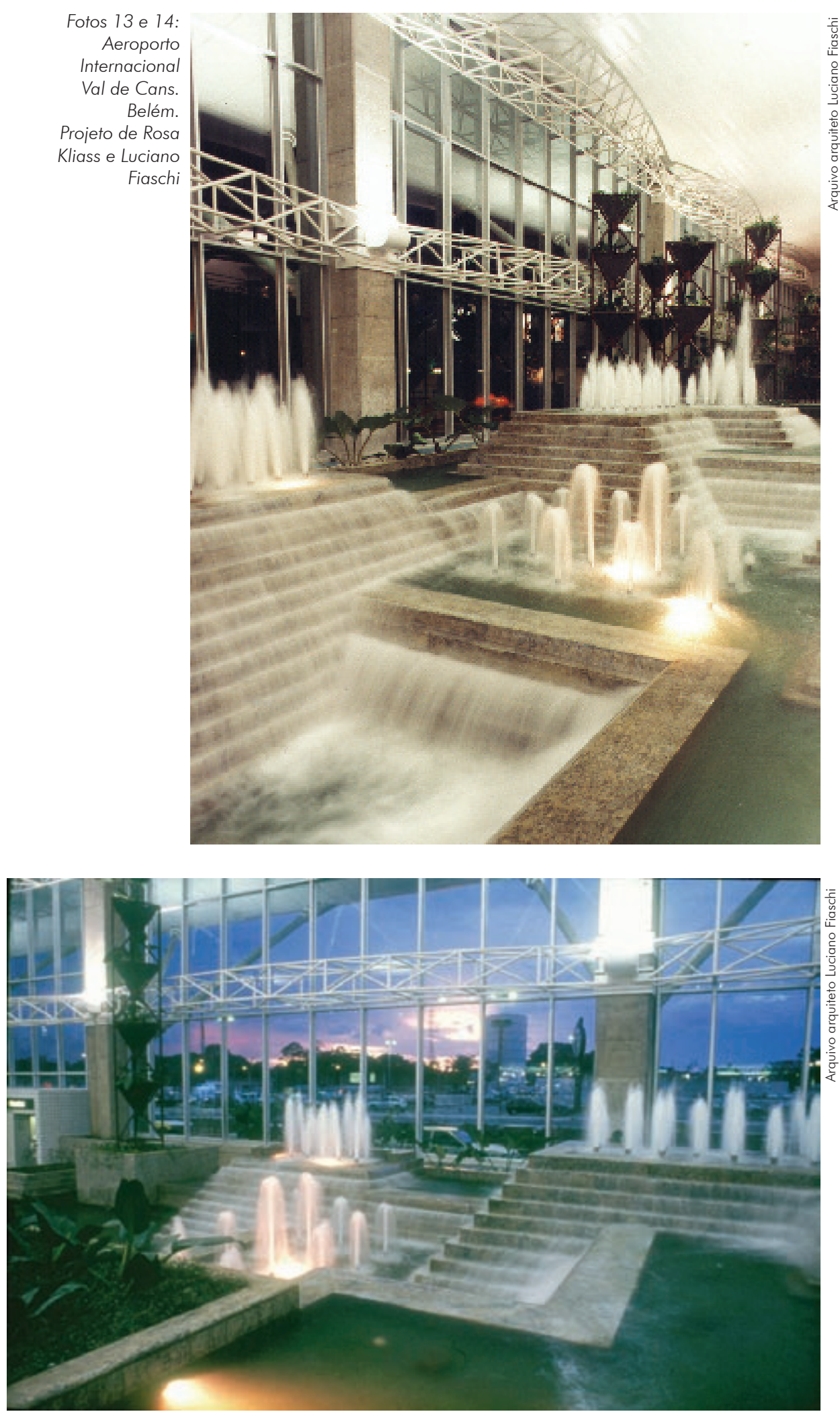
Uma coisa que já tinha ouvido da Esther, quando participei de um concurso da Paulista, é que a pior coisa que existe nessa avenida é a parede do canteiro central representada pelo alinhamento dos postes. Achei muito oportuno a Esther propor a retirada dos postes do canteiro central, pois, na realidade, iluminam as fachadas dos prédios, deixando as calçadas escuras. Estou dando palpites e vibrando com as colocações da Esther e do Cauduro. Acho que o projeto está aprovado e já está sendo divulgado.

Existe o cliente que sabe o que é um projeto de paisagismo e sabe a contribuição que você pode dar. Por outro lado, virou uma coisa que tem muita gente fazendo - mal. Eu consigo competir cobrando $R \$ 10.000,00$, concorrendo com uma pessoa que cobra R\$1.000,00. Mostro o que faço e o cliente me escolhe. Nunca coloquei uma placa em obra e tenho clientes que me procuram para a sexta, sétima, oitava obra, inclusive obra residencial. Eu já estou fazendo obras para filhos e netos de clientes, porque sabem como é meu trabalho. Mas tem muito mais gente concorrendo. Acho que deve ser dificílimo para quem começa. Depois que você forma uma clientela, não tem mais problemas. Tem muita gente fazendo projeto quase de graça. $E$, por outro lado, um projeto não vale mais nada. Tem cliente que gasta, em um único jantar para amigos no Fasano, o dobro do que pagaria em um projeto. É uma questão de valores. Conseguir cobrar por um projeto o que ele vale é muito complicado. Tem cliente que pergunta se poderia cobrar $1 / 3$ do valor, fazendo 1/3 do projeto; eu digo que não, porque não poderia desenvolver o projeto até onde quero.

Tenho um esquema romântico de não ter dez arquitetos trabalhando em meu escritório, porque não conseguiria controlar os dez. Controlo no máximo três e já acho muito. Quero o arquiteto envolvido no projeto, tomando decisões. Não trabalho com desenhista ou estagiário. 